\title{
Correlation of the Lipolytic Action of Synthetic Peptides with Their Structures: Importance of Acidic and Basic Amino Acid Residues in the N-Terminal Region
}

\author{
Hiroshi Masuno, ${ }^{*, 1)}$ Hisako Nakamura, * Takeshi Ohara, \\ Hiromi Yamashita, Kumiko Funaki, Yojiro NaKa, \\ Akio IDE ${ }^{\dagger}$ and Hiromichi OKUDA* \\ Laboratory of Biochemistry, Faculty of Agriculture, Yamaguchi University, \\ Yamaguchi 753, Japan \\ * Department of Medical Biochemistry, School of Medicine, \\ Ehime University, Shigenobu, Onsen-gun, \\ Ehime 791-02, Japan
}

Received November 2, 1987

\begin{abstract}
The effects on lipolysis in fat cells of synthetic peptides with different amino acid residues added to the $\mathrm{N}$-terminal region of the sequence Phe-Phe-Phe were examined. Several synthetic peptides elicited free fatty acid (FFA) release from fat cells, the order of efficacy of their lipolytic actions being, Arg-Glu- Arg-Glu-Gly-> Glu-Arg-Gly-> Lys-Asp- Lys-Asp-Gly- Glu-Arg- > Asp-Lys-Gly-. $\operatorname{Arg}\left(\mathrm{NO}_{2}\right)$-Glu-Gly-Gly-Phe-Phe-Phe did not cause any release of FFA from fat cells.

Arg-Glu-Phe-Phe-Phe stimulated lipolysis of fat cells even when calcium ions were not present in the reaction mixture, but other peptides required calcium ions for their lipolytic actions. The $\beta$-adrenergic blocker propranolol completely inhibited the lipolysis stimulated by Arg-Glu-GlyPhe-Phe-Phe or Arg-Glu-Phe-Phe-Phe. The $\alpha$-adrenergic blocker phenoxybenzamine had little effect on the lipolytic action stimulated by these two peptides.

Lys-Asp-Gly-Phe-Phe-Tyr and Asp-Lys-Gly-Phe-Phe-Tyr also stimulated lipolysis, the stimulatory effect of the latter being about $58 \%$ of that of the former. Glu-Arg-Gly-Phe-Phe-Tyr and Arg-Glu-Gly-Phe-Phe-Tyr did not cause any release of FFA from fat cells.
\end{abstract}

One approach to study of the actions of lipolytic hormones in molecular level is to investigate the relationship between the structure and activity of chemically or enzymatically modified hormones and synthetic peptides. In this work we tried to identify the parts of synthetic peptides responsible for a lipolytic effect by finding which amino acid residues were necessary for this effect.

Previously, we reported that Glu-Arg-GlyPhe-Phe-Phe stimulated lipolysis in fat cells. ${ }^{1}$ ) Replacement of Phe at the C-terminus by a tyrosine residue resulted in loss of its effect in eliciting free fatty acid (FFA) release from fat cells. We suggested that the presence of an $\mathrm{OH}$ group at the $\mathrm{C}$-terminus might interfere with binding to appropriate receptors or change the conformation of the peptide. Other workers have reported the importance of a guanidino group in the insulin molecule ${ }^{2)}$ and ACTH molecule $^{3)}$ for biological activities.

In this study, we investigated the importance of the basic and acidic amino acid residues in the N-terminal region of drivatives of GluArg-Gly-Phe-Phe-Phe and Glu-Arg-Gly-PhePhe-Tyr for a lipolytic effect.

$\dagger$ To whom correspondence should be addressed.

Abbreviations: FFA, free fatty acid; ACTH, adrenocorticotropic hormone; $Z$, benzyloxycarbonyl; Boc, $t$-butyloxycarbonyl; ONp, O-p-nitrophenyl; OBzl, $O$-benzyl; OEt, $O$-ethyl; DMF, dimethylformamide; THF, tetrahydrofuran. 


\section{MATERIALS AND METHODS}

Materials. Bovine albumin (fraction $\mathrm{V}$ from bovine plasma) was obtained from Wako Pure Chemicals, Co., Ltd., Osaka. Collagenase (type I) was obtained from Worthington Biochemical Co., Freehold, NJ. Synthetic ACTH (Cortrosyn injection) was purchased from Daiichi Seiyaku Co., Ltd., Tokyo. D,L-Propranolol hydrochloride and phenoxybenzamine hydrochloride were obtained from Nakarai Chemicals, Kyoto. Other chemicals were from Wako.

Syntheses of peptides. Peptides were synthesized by stepwise elongation from the $\mathrm{C}$-terminus in a liquid phase. As an example, the synthesis of Arg-Glu-Gly-Phe-Phe-Phe is shown below. The yields and physicochemical properties of the peptide intermediate are summarized in Table I. Elemental analyses of these compounds gave reasonable values (data not shown). The $R f$ values shown were those obtained by thin layer chromatography on Avicel in the following solvents: (a), BuOH-AcOH$-\mathrm{H}_{2} \mathrm{O} \quad(4: 1: 1$, $\mathrm{v} / \mathrm{v} / \mathrm{v}) ;(\mathrm{b}), \mathrm{BuOH}-\mathrm{AcOH}-\mathrm{H}_{2} \mathrm{O}(4: 1: 2, \mathrm{v} / \mathrm{v} / \mathrm{v})$.

Arg-Glu-Gly-Phe-Phe-Phe (1). Z-Phe-Phe-Phe-OEt ${ }^{1\}}$ $(2.49 \mathrm{~g})$ was treated with $25 \% \mathrm{HBr}-\mathrm{AcOH}(30 \mathrm{ml})$ in the presence of anisole $(2 \mathrm{ml})$ for $1 \mathrm{hr}$. After concentration, the residue was treated with dry $\mathrm{Et}_{2} \mathrm{O}$ and dried in a desicator containing $\mathrm{NaOH}$ pellets. The resultant solid was mixed with $\mathrm{Et}_{3} \mathrm{~N}(1.2 \mathrm{~g})$ and $\mathrm{Z}$-Gly-ONp ${ }^{4}(1.58 \mathrm{~g})$ in THF. After 3 days, the mixture was diluted with $\mathrm{H}_{2} \mathrm{O}$. The resulting solid was washed with $1 \mathrm{~N} \mathrm{NH}_{3}$ solution, $\mathrm{H}_{2} \mathrm{O}, 5 \%$ citric acid, and $\mathrm{H}_{2} \mathrm{O}$, and recrystallized from a mixture of THF and $\mathrm{H}_{2} \mathrm{O}$ to give coloriess crystals $(2.50 \mathrm{~g})$ as Z-Gly-PhePhe-Phe-OEt. The dried product $(2.01 \mathrm{~g})$ was treated as described above. The product was mixed with Boc$\left.\mathrm{Glu}(\mathrm{OBzl})-\mathrm{ONp}^{5}\right)(0.69 \mathrm{~g})$ and $\mathrm{Et}_{3} \mathrm{~N}(0.15 \mathrm{~g})$ in dry DMF. The mixture was stirred for 3 days at room temperature and treated as above to give colorless powdery crystals (from a mixture of THF and hexane) of Boc-Glu(OBzl)Gly-Phe-Phe-Phe-OEt, mp $137 \sim 140^{\circ} \mathrm{C}$. After removal of

Table 1. Yields and Physicochemical Properties of Peptide Intermediates

\begin{tabular}{|c|c|c|c|c|}
\hline Peptide intermediates ${ }^{a}$ & $\begin{array}{l}\text { Yield } \\
(\%)\end{array}$ & $\begin{array}{c}\mathrm{mp} \\
\left({ }^{\circ} \mathrm{C}\right)\end{array}$ & $\begin{array}{c}{[\alpha]_{\mathrm{D}}^{b}} \\
(c=1, \mathrm{DMF})\end{array}$ & $R f(\text { solv. })^{c}$ \\
\hline Z-Gly-Phe-Phe-Phe-OEt & 91.1 & $184 \sim 186$ & -6.0 & $0.52(3), 0.28(1)$ \\
\hline Boc-Glu(OBzl)-Gly-Phe-Phe-Phe-OEt & 70.3 & $137 \sim 140$ & -16.1 & $0.55(3)$ \\
\hline Boc-Arg( $\left.\mathrm{NO}_{2}\right)$-Glu(OBzl)-Gly-Phe-Phe-Phe-OEt & 58.3 & $187 \sim 190$ & -3.4 & $0.50(2)$ \\
\hline Boc-Asp(OBzl)-Gly-Phe-Phe-Phe-OEt & 69.4 & $183 \sim 184$ & -13.9 & $0.67(3), 0.41(2)$ \\
\hline Boc-Lys(Z)-Asp(OBzl)-Gly-Phe-Phe-Phe-OEt & 92.4 & $168 \sim 170$ & -16.9 & $0.59(3), 0.59(2)$ \\
\hline Boc-Lys(Z)-Gly-Phe-Phe-Phe-OEt & 56.3 & $157 \sim 158$ & -11.5 & $0.68(3)$ \\
\hline Boc-Asp(OBzl)-Lys(Z)-Gly-Phe-Phe-Phe-OEt & 64.0 & $142 \sim 144$ & -22.3 & $0.53(3)$ \\
\hline Boc-Arg $\left(\mathrm{NO}_{2}\right)$-Phe-Phe-Phe-OEt & 92.4 & $184 \sim 188$ & $-16.5^{d}$ & $0.16(3)$ \\
\hline Boc-Glu( $(\mathrm{OBzl})-\mathrm{Arg}\left(\mathrm{NO}_{2}\right)$-Phe-Phe-Phe-OEt & 82.8 & $156 \sim 158$ & -20.4 & $0.51(3), 0.46(4)$ \\
\hline Boc-Glu(OBzl)-Phe-Phe-Phe-OEt & 68.3 & $167 \sim 170$ & -14.7 & $0.69(3), 0.81(2)$ \\
\hline Boc-Arg( $\left.\mathrm{NO}_{2}\right)$-Glu(OBzl)-Phe-Phe-Phe-OEt & 43.8 & 133 & $-19.1^{e}$ & $0.59(3), 0.51(4)$ \\
\hline Boc-Lys(Z)-Phe-Phe-Phe-OEt & 68.8 & $150 \sim 151$ & -16.7 & $0.10(1)$ \\
\hline Z-Asp(OMe)-Lys(Z)-Phe-Phe-Phe-OEt & 72.0 & $160 \sim 162$ & $-12.7^{e}$ & $0.15(1)$ \\
\hline Z-Asp(OMe)-Phe-Phe-Phe-OEt & 45.0 & $150 \sim 153$ & -23.8 & $0.72(1)$ \\
\hline Boc-Lys(Z)-Asp(OMe)-Phe-Phe-Phe-OEt & 35.6 & $143 \sim 145$ & -17.4 & $0.65(1)$ \\
\hline Z-Lys(Z)-Asp(OMe)-Phe-Phe-Phe-OEt & 88.2 & $165 \sim 168$ & -25.4 & $0.56(2)$ \\
\hline Z-Gly-Phe-Phe-Tyr-OEt & 63.3 & $112 \sim 114$ & -12.2 & $0.65(4), 0.34(2)$ \\
\hline Boc-Glu(OBzl)-Gly-Phe-Phe-Tyr-OEt & 60.3 & $123 \sim 124$ & -10.2 & $0.23(2), 0.58(4)$ \\
\hline Boc-Arg( $\left.\mathrm{NO}_{2}\right)$-Glu(OBzl)-Gly-Phe-Phe-Tyr-OEt & 78.3 & 118 & -5.3 & $0.21(4)$ \\
\hline Boc-Lys(Z)-Gly-Phe-Phe-Tyr-OEt & 79.7 & $127 \sim 130$ & 1.3 & $0.74(3)$ \\
\hline Boc-Asp(OBzl)-Lys(Z)-Gly-Phe-Phe-Tyr-OEt & 49.3 & $172 \sim 175$ & -7.8 & $0.85(3)$ \\
\hline Boc-Asp(OBzl)-Gly-Phe-Phe-Tyr-OEt & 30.8 & $163 \sim 165$ & -5.2 & $0.21(2)$ \\
\hline Boc-Lys(Z)-Asp(OBzl)-Gly-Phe-Phe-Tyr-OEt & 77.1 & $\mathrm{ND}^{f}$ & -8.6 & $0.60(4)$ \\
\hline
\end{tabular}

a Abbreviations: $Z$, benzyloxycarbonyl; Boc, $t$-butyloxycarbonyl; OBzl, $O$-benzyl; OEt, $O$-ethyl; OMe, $O$-methyl.

$b$ Optical rotation was measured in a JASCO DIP-140 spectropolarimeter.

c Thin layer chromatography was done on a silica gel $\mathrm{GF}_{254}$ (Merck) plate. Solvent systems were (1), AcOEthexane $(1: 1, \mathrm{v} / \mathrm{v}) ;(2)$, AcOEt-hexane $(2: 1, \mathrm{v} / \mathrm{v}) ;(3), \mathrm{CHCl}_{3}-\mathrm{AcOEt}-\mathrm{MeOH}(4: 2: 1, \mathrm{v} / \mathrm{v} / \mathrm{v}) ;(4), \mathrm{CHCl}_{3}-$ benzene-MeOH $(2: 2: 1, \mathrm{v} / \mathrm{v} / \mathrm{v})$.

d Concentration is $0.1 \%$.

e Concentration is $0.9 \%$.

$f$ Not determined. 
the Boc-residue of the peptide $(0.78 \mathrm{~g})$, the amine component was treated with $N$-methylmorpholine $(0.11 \mathrm{~g})$ and a mixed anhydride, which was prepared from Boc$\operatorname{Arg}\left(\mathrm{NO}_{2}\right)(0.32 \mathrm{~g})$ and $\mathrm{N}$-methylmorpholine $(0.11 \mathrm{~g})$ and isobutylchloroformate $(0.13 \mathrm{~g})$ in $\mathrm{DMF}$ at $-11^{\circ} \mathrm{C}$. The reaction mixture was diluted with $\mathrm{H}_{2} \mathrm{O}$, and the resultant precipitate was washed with saturated $\mathrm{Na}_{2} \mathrm{SO}_{4}$ solution, $\mathrm{NaHCO}_{3}$ solution, $5 \%$ citric acid and saturated $\mathrm{Na}_{2} \mathrm{SO}_{4}$ solutions, and recrystallized from a mixture of THF and hexane to give $0.45 \mathrm{~g}$ of colorless crystals as Boc$\operatorname{Arg}\left(\mathrm{NO}_{2}\right)-\mathrm{Glu}(\mathrm{OBz})$-Phe-Phe-Phe-OEt.

The above protected hexapeptide $(0.50 \mathrm{~g})$ in DNF solution was mixed with $1 \mathrm{ml}$ of $2 \mathrm{~N} \mathrm{KOH}$ and acidified with $5 \%$ citric acid after a day. The resulting precipitate was collected, washed with $\mathrm{H}_{2} \mathrm{O}$, dried in a dessicator, and treated with $\mathrm{HF}$ in the presence of anisole. $\mathrm{HF}$ was evaporated and the residue was dissolved in $1 \mathrm{~N} \mathrm{AcOH}$. The aqueous solution was washed with $\mathrm{Et}_{2} \mathrm{O}$ and passed through a Dowex $1 \times 2$ (acetate form) column with $1 \mathrm{~N}$ $\mathrm{AcOH}$. The eluate was concentrated to dryness and the residue was purified by chromatography of a Sephadex $\mathrm{G}$ 10 column (length, $110 \mathrm{~cm}$; diam., $15 \mathrm{~mm}$; a fraction, $5 \mathrm{ml}$ ). The column was eluted with $20 \%$ EtOH. Fractions No. 43 to 53 were collected. The combined fractions were concentrated to dryness in vacuo to give $0.15 \mathrm{~g}(32.3 \%)$ of amorphous powder. Rf: 0.43 (solv. b). Amino acid ratios in a $6 \mathrm{~N} \mathrm{HCl}$ hydrolysate: Arg, 1.05; Glu, 1.05; Gly, 1.00; Phe, 2.85

Lys-Asp-Phe-Phe-Phe (2). Boc-Lys(z)-Asp(OBzl)-GlyPhe-Phe-Phe-OEt was obtained from Z-Gly-Phe-Phe-PheOEt by stepwise elongation in the manner described above. The protected hexapeptide $(1.0 \mathrm{~g})$ was treated similarly to that described above, but with $25 \% \mathrm{HBr} /$ AcOH instead of HF. Yield, $0.52 \mathrm{~g}(63.0 \%$ ). $R f, 0.83$ (solv. a). Amino acid ratios in a $6 \mathrm{~N} \mathrm{HCl}$ hydrolysate: Lys, 0.95 ; Asp, 1.03; Gly, 1.00; Phe, 3.31 .

Asp-Lys-Gly-Phe-Phe-Phe (3). This peptide was prepared from Boc-Lys(Z)-Gly-Phe-Phe-Phe-OEt similarly to that noted for 2. Yield $0.18 \mathrm{~g}(53.0 \%)$. $R f: 0.81$ (solv a). Amino acid ratios in the $6 \mathrm{~N} \mathrm{HCl}$ hydrolysate: Asp, 1.03; Lys, 0.92; Gly, 1.00; Phe, 2.85.

Glu-Arg-Phe-Phe-Phe (4). Boc-Glu-(OBzl)Arg( $\left.\mathrm{NO}_{2}\right)_{-}$ Phe-Phe-Phe-OEt was prepared from Z-Phe-Phe-Phe-OEt by stepwise elongation. The protected hexapeptide $(0.50 \mathrm{~g})$ was treated as described for preparation of 1 . Yield. $0.24 \mathrm{~g}$ $(56 \%$ ). $R f: 0.57$ (solv. b). Amino acid ratios in a $6 \mathrm{~N} \mathrm{HCl}$ hydrolysate: Glu, 0.89; Arg, 0.97; Phe, 3.00.

Arg-Glu-Phe-Phe-Phe (5). This peptide was prepared essentially as described above. Yield $0.27 \mathrm{~g}(63.0 \%)$. Rf: 0.31 (solv. a). Amino acid ratios in a $6 \mathrm{~N} \mathrm{HCl}$ hydrolysate: Arg, 0.98; Glu; 0.91; Phe, 3.00.

Asp-Lys-Phe-Phe-Phe (6). This peptide was prepared from Z-Phe-Phe-Phe-OEt similarly to that noted for 2 . Yield: $0.17 \mathrm{~g}(84.3 \%$ ). $R f: 0.36$ (solv. b). Amino acid ratios in a $6 \mathrm{~N} \mathrm{HCl}$ hydrolysate: Asp, 1.11; Lys, 1.00; Phe 3.30.

Lys-Asp-Phe-Phe-Phe (7). This peptide was prepared similarly to that noted for 2. $R f: 0.49$ (solv. b). Amino acid ratios in a $6 \mathrm{~N} \mathrm{HCl}$ hydrolysate: lys, 1.00; Asp, 1.10; Phe, 3.40 .

Arg-Glu-Gly-Phe-Phe-Tyr (8). Deblocking of the protected hexapeptide, Boc-Arg( $\left.\mathrm{NO}_{2}\right)$-Glu-(OBzl)-Gly-PhePhe-Tyr-OEt $(0.66 \mathrm{~g})$ was done as described for the preparation of 1. Yield: $0.15 \mathrm{~g}(26.0 \%) . R f: 0.15$ (solv. a). Amino acid ratios in a $6 \mathrm{~N} \mathrm{HCl}$ hydrolysate: $\mathrm{Arg}, 0.92$; Glu, 1.03; Gly, 1.00; Phe, 2.13; Tyr, 1.10.

Lys-Asp-Gly-Phe-Phe-Tyr (9). Boc-Lys(Z)-Asp-(OBzl)Gly-Phe-Phe-Tyr-OEt $(0.40 \mathrm{~g})$ was deblocked as described for preparation of 2. Yield: $0.21 \mathrm{~g}(65.0 \%) . R f: 0.13$ (solv. b). Amino acid ratios in a $6 \mathrm{~N} \mathrm{HCl}$ hydrolysate: Lys, 1.02; Asp, 1.01; Gly, 1.00; Phe, 2.30; Tyr, 0.96 .

Asp-Lys-Gly-Phe-Phe-Tyr (10). Boc-Asp(OBzl)-Lys(Z)Gly-Phe-Phe-Tyr-OEt $(0.67 \mathrm{~g})$ was deblocked as described for (2) except that a Biogel P-2 column was used for the purification. Yield: $0.15 \mathrm{~g}(22.4 \%)$. Rf: 0.34 (solv. b). Amino acid ratios in a $6 \mathrm{~N} \mathrm{HCl}$ hydrolysate: Asp, 1.10 ; Lys, 1.10; Gly, 1.00; Phe, 2.30; Tyr, 0.95 .

Estimation of lipolysis. Fat cells were isolated from the adipose tissue of male Wistar rats (weighing $150 \sim 180 \mathrm{~g}$ ) by the method of Rodbell. ${ }^{6}$ The lipolytic action of the peptides was measured as described previously ${ }^{11}$ as follows. The isolated fat cells were incubated with peptides at $37^{\circ} \mathrm{C}$ for $2 \mathrm{hr}$ in Krebs-Ringer bicarbonate buffer ( $\mathrm{pH} 7.4$ ) containing $2.5 \%$ bovine albumin in the presence and absence of $\mathrm{CaCl}_{2}$ or in the presence and absence alphaand beta-adrenagic blocker. The released FFA was measured by the method of Fahlholt ${ }^{17)}$ with slight modifications. The details are in the liaterature. ${ }^{1)}$

\section{RESULTS}

\section{Lipolytic effects of derivatives of Glu-Arg-Gly- Phe-Phe-Phe}

The effects of synthetic peptides on lipolysis in the presence of $2.5 \mathrm{mM} \mathrm{CaCl}_{2}$ were examined (Table II). All the peptides except Asp-LysPhe-Phe-Phe elicited FFA release from fat cells. Arg-Glu-Gly-Phe-Phe-Phe induced a dose-dependent increase in FFA release (Fig. 1a). Glu-Arg-Gly-Phe-Phe-Phe also induced FFA release dose-dependently. The minimum effective concentration of Arg-Glu-Gly-Phe- 
Table II. Effects of Synthetic Peptides on Lipolysis in Fat Cells ${ }^{a}$

\begin{tabular}{lll}
\hline & $\begin{array}{c}\text { Concentration } \\
(\mu \mathrm{mol} / \mathrm{ml})\end{array}$ & $\begin{array}{c}\text { FFA Released } \\
(\mu \mathrm{mol} / 100 \mathrm{mg} / 2 \mathrm{hr})\end{array}$ \\
Exp. 1. & 0.5 & $0.08 \pm 0.01$ \\
None & 0.5 & $0.72 \pm 0.03^{*}$ \\
Glu-Arg-Gly-Phe-Phe-Phe & 0.5 & $1.29 \pm 0.12^{*}$ \\
Arg-Glu-Gly-Phe-Phe-Phe & 0.5 & $0.19 \pm 0.03^{* *}$ \\
Asp-Lys-Gly-Phe-Phe-Phe & & $0.41 \pm 0.14^{* *}$ \\
Lys-Asp-Gly-Phe-Phe-Phe & - & $0.09 \pm 0.02$ \\
Exp. 2. & 0.5 & $0.32 \pm 0.05^{*}$ \\
None & 0.5 & $1.34 \pm 0.03^{*}$ \\
Glu-Arg-Phe-Phe-Phe & 0.5 & $0.08 \pm 0.03$ \\
Arg-Glu-Phe-Phe-Phe & 0.5 & $0.59 \pm 0.15^{*}$ \\
Asp-Lys-Phe-Phe-Phe & & $0.05 \pm 0.02$ \\
Lys-Asp-Phe-Phe-Phe & - & $0.07 \pm 0.03$ \\
Exp. 3. & 0.5 & - \\
None & & \\
Arg(NO $\left.{ }_{2}\right)$-Glu-Gly-Phe-Phe-Phe & &
\end{tabular}

a Isolated fat cells were incubated with or without a peptide at $37^{\circ} \mathrm{C}$ for $2 \mathrm{hr}$ in $\mathrm{Krebs}-\mathrm{Ringer}$ bicarbonate buffer ( $\mathrm{pH} 7.4$ ) containing $2.5 \%$ bovine albumin and $2.5 \mathrm{mM} \mathrm{CaCl}_{2}$.

$b \quad$ Mean \pm SE $(n=3)$.

** $p<0.05,{ }^{* *} p<0.01$ (Student's $t$-test, compared with FFA released in the absence of peptide).

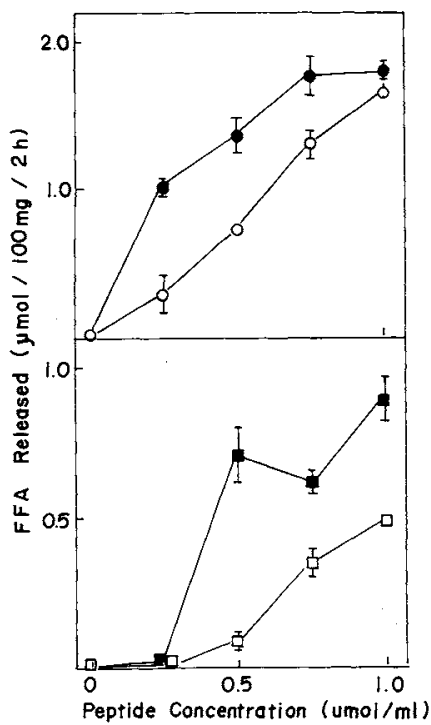

FIG. 1. Effects of Synthetic Peptides on Lipolysis in Fat Cells.

Isolated fat cells were incubated with the peptide at $37^{\circ} \mathrm{C}$ for $2 \mathrm{hr}$ in Krebs-Ringer bicarbonate buffer ( $\mathrm{pH}$ 7.4) containing $2.5 \%$ bovine albumin and $2.5 \mathrm{mM} \mathrm{CaCl}_{2}$. Arg-Glu-Gly-Phe-Phe-Phe; $\bigcirc$, Glu-Arg-Gly-Phe-PhePhe; $\square$, Lys-Asp-Gly-Phe-Phe-Phe; $\square$, Asp-Lys-Gly-PhePhe-Phe. Bars indicate standard errors for triplicate experiments. ${ }^{*} p<0.01$ by Student's $t$-test, compared with FFA released in the absence of the peptide.

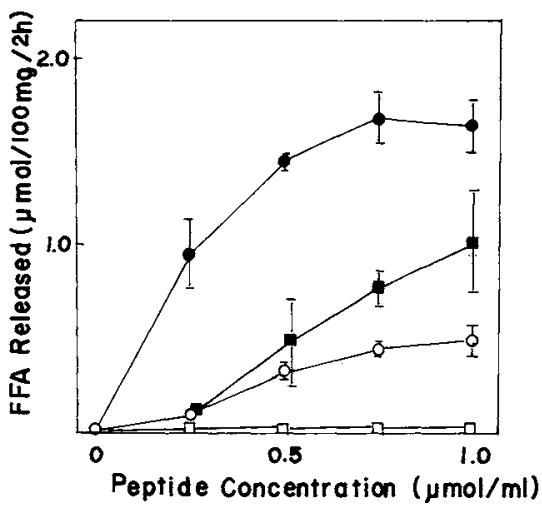

FIG. 2. Effects of Synthetic Peptides on Lipolysis in Fat Cells.

Assay conditions were as described for Fig. 1. O, ArgGlu-Phe-Phe-Phe; O, Glu-Arg-Phe-Phe-Phe; $\square$, Lys-AspPhe-Phe-Phe; $\square$, Asp-Lys-Phe-Phe-Phe. Bars indicate standard errors for triplicate experiments. ${ }^{* *} p<0.05$, $* p<0.01$ by Student's $t$-test, compared with FFA released in the absence of the peptide.

Phe-Phe was $0.25 \mu \mathrm{mol} / \mathrm{ml}$, but that of GluArg-Gly-Phe-Phe-Phe was $0.50 \mu \mathrm{mol} / \mathrm{ml}$, and the stimulatory effect of the former $(0.50$ $\mu \mathrm{mol} / \mathrm{ml})$ on lipolysis was about $180 \%$ of that of the latter $(0.50 \mu \mathrm{mol} / \mathrm{ml})$ (Table II). Lys-Asp-Gly-Phe-Phe-Phe and Asp-Lys-Gly- 
Phe-Phe-Phe also stimulated lipolysis, their minimum effective concentrations being 0.50 and $0.75 \mu \mathrm{mol} / \mathrm{ml}$, respectively (Fig. $1 \mathrm{~b}$ ). Their effects were lower than those of Arg-Glu-GlyPhe-Phe-Phe and Glu-Arg-Gly-Phe-Phe-Phe (Table II).

The importance of a Gly residue for a stimulatory effect on lipolysis was examined (Table II). The stimulatory effect of Arg-GluPhe-Phe-Phe on lipolysis was similar to that of Arg-Glu-Gly-Phe-Phe-Phe and the effects of the two were dose-dependent (Figs. 1 and 2). Removal of the Gly residue from Lys-AspGly-Phe-Phe-Phe caused a slight but not significant increase in efficacy. The stimulatory effects of the other peptides on lipolysis were reduced by removal of the Gly residue, and re- moval of the Gly residue from Glu-Arg-GlyPhe-Phe-Phe decreased the potency to $44 \%$. Removal of the Gly residue from Asp-LysGly-Phe-Phe-Phe resulted in loss of effect on the release of FFA.

The importance of the free guanidino group of $\mathrm{Arg}$ for a stimulatory effect on lipolysis was studied. The peptide $\operatorname{Arg}\left(\mathrm{NO}_{2}\right)$-Glu-Gly-PhePhe-Phe, in which the guanidino group was blocked by a nitro group, did not cause any release of FFA (Table II).

Lipolytic effects of derivatives of Glu-Arg-GlyPhe-Phe-Tyr

The lipolytic effects of synthetic peptides in which the Phe residue at the $\mathrm{C}$-terminus was replaced by a $\mathrm{Tyr}$ residue were examined

Table III. Effects of Synthetic Peptides on Lipolysis in Fat Cells ${ }^{a}$

\begin{tabular}{lcc}
\hline & $\begin{array}{c}\text { Concentration } \\
(\mu \mathrm{mol} / \mathrm{ml})\end{array}$ & $\begin{array}{c}\text { FFA Released } \\
(\mu \mathrm{mol} / 100 \mathrm{mg} / 2 \mathrm{hr})\end{array}$ \\
\hline None & - & $0.08 \pm 0.03^{b}$ \\
Glu-Arg-Gly-Phe-Phe-Tyr & 0.5 & $0.08 \pm 0.03$ \\
Arg-Glu-Gly-Phe-Phe-Tyr & 0.5 & $0.10 \pm 0.04$ \\
Asp-Lys-Gly-Phe-Phe-Tyr & 0.5 & $0.65 \pm 0.03^{*}$ \\
Lys-Asp-Gly-Phe-Phe-Tyr & 0.5 & $1.03 \pm 0.02^{*}$ \\
\hline
\end{tabular}

a Isolated fat cells were incubated with or without a peptide at $37^{\circ} \mathrm{C}$ for $2 \mathrm{hr}$ in Krebs-Ringer bicarbonate buffer (pH 7.4) containing $2.5 \%$ bovine albumin and $2.5 \mathrm{mM} \mathrm{CaCl}$.

b Mean $\pm \operatorname{SE}(n=3)$.

* $p<0.01$ (Student's $t$-test, compared with FFA released in the absence of peptide).

Table IV. EfFects of Calcium Ions on Lipolysis in Fat Cells ${ }^{a}$

\begin{tabular}{|c|c|c|c|}
\hline \multirow{2}{*}{ Peptides } & \multirow{2}{*}{$\begin{array}{c}\text { Conc. } \\
(\mu \mathrm{mol} / \mathrm{ml})\end{array}$} & \multicolumn{2}{|c|}{$\begin{array}{c}\text { FFA Released }^{b} \\
(\mu \mathrm{mol} / 100 \mathrm{mg} / 2 \mathrm{hr})\end{array}$} \\
\hline & & $-\mathrm{CaCl}_{2}$ & $+\mathrm{CaCl}_{2}(2 \mathrm{~mm})$ \\
\hline None & - & $0.07 \pm 0.02$ & $0.09 \pm 0.03$ \\
\hline Glu-Arg-Gly-Phe-Phe-Phe & 1.0 & $0.09 \pm 0.01$ & $1.66 \pm 0.03^{*}$ \\
\hline Arg-Glu-Gly-Phe-Phe-Phe & 1.0 & $0.12 \pm 0.03$ & $2.86 \pm 0.07^{*}$ \\
\hline Asp-Lys-Gly-Phe-Phe-Phe & 1.0 & $0.16 \pm 0.09$ & $0.84 \pm 0.07^{*}$ \\
\hline Lys-Asp-Gly-Phe-Phe-Phe & 1.0 & $0.07 \pm 0.02$ & $1.03 \pm 0.09 *$ \\
\hline Glu-Arg-Phe-Phe-Phe & 1.0 & $0.09 \pm 0.02$ & $1.15 \pm 0.04 *$ \\
\hline Arg-Glu-Phe-Phe-Phe & 1.0 & $1.32 \pm 0.01 *$ & $2.81 \pm 0.03^{*}$ \\
\hline Asp-Lys-Phe-Phe-Phe & 1.0 & $0.07 \pm 0.02$ & $0.16 \pm 0.02$ \\
\hline Lys-Asp-Phe-Phe-Phe & 1.0 & $0.17 \pm 0.03$ & $1.53 \pm 0.10^{*}$ \\
\hline
\end{tabular}

a Isolated fat cells were incubated with or without a peptide at $37^{\circ} \mathrm{C}$ for $2 \mathrm{hr}$ in $\mathrm{Krebs}-\mathrm{Ringer}$ bicarbonate buffer ( $\mathrm{pH} 7.4$ ) containing $2.5 \%$ bovine albumin in the absence and presence $(2 \mathrm{mM})$ of $\mathrm{CaCl}_{2}$.

${ }^{b} \quad$ Mean \pm SE $(n=3)$.

* $p<0.01$ (Student's $t$-test, compared with FFA released in the absence of peptide). 
(Table III). Previously, we reported that GluArg-Gly-Phe-Phe-Tyr, which is an insulin Bchain fragment (B21 26), did not cause any release of FFA. ${ }^{1)}$ Arg-Glu-Gly-Phe-Phe-Tyr also had no effect on lipolysis. However, AspLys-Gly-Phe-Phe-Tyr and Lys-Asp-Gly-PhePhe-Tyr stimulated lipolysis, the stimulatory effect of the former being about $58 \%$ of that the latter.

\section{Effects of calcium ions on lipolysis}

The effects of calcium ions on lipolysis in fat cells were examined (Table IV). Calcium ions are known to be essential for ACTHstimulated lipolysis and we confirmed this in this study. Arg-Glu-Phe-Phe-Phe stimulated lipolysis even when calcium ions were not present in the reaction mixture, but its effect was enhanced by the presence of calcium ions. Arg-Glu-Gly-Phe-Phe-Phe did not cause any release of FFA in the absence of calcium ions, and the other peptides also required calcium ions for their stimulatory effects on lipolysis.

TABLE V. EFFECTS OF $\alpha$ - AND $\beta$-ADRENERGIC Blockers on Lipolysis in Fat Cells ${ }^{a}$

\begin{tabular}{|c|c|}
\hline Assay conditions & $\begin{array}{c}\text { FFA Released }^{b} \\
(\mu \mathrm{mol} / 100 \mathrm{mg} / 2 \mathrm{hr})\end{array}$ \\
\hline None & $0.09 \pm 0.03$ \\
\hline $\begin{array}{ll}\text { ACTH }(0.5 \mu \mathrm{g} / \mathrm{ml}) \\
\quad+\text { Phenoxybenzamine } & 10^{-3} \mathrm{M} \\
\quad \text { + Propranolol } & 10^{-3} \mathrm{M}\end{array}$ & $\begin{array}{c}1.14 \pm 0.02 * \\
1.30 \pm 0.05^{*} \\
0.05 \pm 0.02\end{array}$ \\
\hline 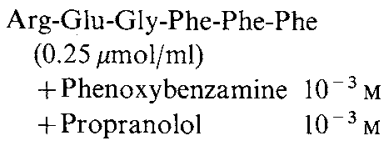 & $\begin{array}{l}1.16 \pm 0.06^{*} \\
1.39 \pm 0.03^{*} \\
0.08 \pm 0.04\end{array}$ \\
\hline 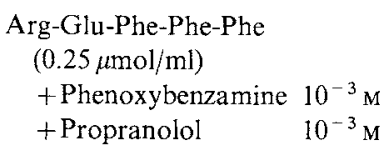 & $\begin{array}{l}1.03 \pm 0.04 * \\
1.24 \pm 0.19 * \\
0.10 \pm 0.04\end{array}$ \\
\hline
\end{tabular}

a Isolated fat cells were incubated with or without a peptide at $37^{\circ} \mathrm{C}$ for $2 \mathrm{hr}$ in Krebs-Ringer bicarbonate buffer ( $\mathrm{pH} 7.4$ ) containing $2.5 \%$ bovine albumin and $2.5 \mathrm{~mm} \mathrm{CaCl}_{2}$ in the absence and presence of $\alpha$ - and $\beta$-adrenergic blocker.

b Mean $\pm \mathrm{SE}(n=3)$.

* $p<0.01$ (Student's $t$-test, compared with FFA released in the absence of peptide).
Effects of $\alpha$ - and $\beta$-adrenergic blockers on lipolysis

To find whether the lipolytic actions of ArgGlu-Gly-Phe-Phe-Phe and Arg-Glu-Phe-PhePhe were mediated by stimulation of $\alpha$ - and $\beta$ adrenergic receptors, we examined the $\alpha$ adrenergic blocker, phenoxybenzamine, and the $\beta$-adrenergic blocker, propranolol, on lipolysis (Table V). Effects of the propranolol completely blocked lipolysis stimulated by both peptides as well as ACTH, but phenoxybenzamine had no effect on lipolysis stimulated by these peptides.

\section{DISCUSSION}

This study demonstrated that synthetic peptides elicited FFA release from fat cells, but that their efficacies depended on the structure and sequences of the amino acid residues added to the $\mathrm{N}$-terminal region of the sequence Phe-Phe-Phe (Table II). The order of potencies of these peptides was: Arg-Glu- $\sim$ Arg-GluGly- > Glu-Arg-Gly- > Lys-Asp- Lys-AspGly- Glu-Arg- > Asp-Lys-Gly-. Replacement of Glu-Arg by Arg-Glu in the N-terminal region resulted in a marked increase in stimulation of FFA release from fat cells. Replacement of Asp-Lys by Lys-Asp also resulted in an increase in FFA release, but replacement of Arg-Glu by Lys-Asp led to a great decrease in efficacy of the lipolytic action.

These results show that the sequence and species of amino acid residues in the $\mathrm{N}$ terminal region affect the potency of the lipolytic action of the peptides. Peptides with an $\mathrm{N}$-terminal basic amino acid residue had higher stimulatory effects on lipolysis than those with an $\mathrm{N}$-terminal acidic amino acid residue (Tables II and III).

Some reasons why the efficacies of the lipolytic actions of these peptides differed may be considered. First, exchange or replacement of the amino acid residues at the $\mathrm{N}$-terminal region may lead to decrease in efficacies of the lipolytic action by decreasing the affinity for the receptor depending on the structure of the amino acid residues. These peptides differ not 
only in the $\mathrm{p} K_{\mathrm{a}}$ values of these basic and acidic groups, but also in the lengths of their aliphatic chains that carry the basic and acidic groups. Tesser et al. $^{3)}$ reported that the presence of a guanidino group in position 8 of the ACTH peptide is essential for the biological activities, but that length of the aliphatic chain carrying the guanidino group is of minor importance. In this study, we showed that replacement of Arg-Glu by Lys-Asp led to a decrease in potency of the lipolytic action and that blocking the free guanidino group of Arg with nitro group resulted in loss of FFA release (Table II). Yamasaki et al. ${ }^{7)}$ reported that blocking the free amino group of bovine growth hormone with an acetyl group caused a marked decrease in potency of its lipolytic action. These results suggest that a free guanidino or amino group may be important for a lipolytic action on fat cells. Second, the different efficacies of lipolytic action may be due to conformational changes of the peptides. The Gly residue was essential for higher effects on the lipolytic action in peptides that have an acidic amino acid residue at the $\mathrm{N}$-terminus, but not in those that have basic amino acid residues (Table II). The Gly residue may constitute a hinge between the hydrophilic (Nterminal) and hydrophobic (C-terminal) regions and a flexible hinge might be essential for the lipolytic action of peptides with the sequence Glu-Arg or Asp-Lys in the $\mathrm{N}$ terminal region. There are reports that hinge regions in peptides are important for their activities. ${ }^{8,9)}$

Replacement of Phe by Tyr at the Cterminus of Glu-Arg-Gly-Phe-Phe-Phe and Arg-Glu-Gly-Phe-Phe-Phe resulted in loss of activities for FFA release from fat cells (Table III). In contrast, replacement of Phe by Tyr in the C-terminus of peptides with Asp-Lys or Lys-Asp in the N-terminal region elicited lipolytic action. This appearance of lipolytic action might be due to loss of the steric hindrance of the $\mathrm{OH}$ group of Tyr on binding to the receptors.

The mechanism by which the peptides studies in this work elicited FFA release from fat cells is still unknown. It is generally accepted that the initial event in hormonal action involves stereospecific combination between the hormone and its receptor. The lipid phase of the target cell membrane is thought to regulate the intrinsic affinity of the receptors for peptides. ${ }^{10)}$ Schwyzer and his coworkers reported that ACTH 1-24 was adsorbed to pure lipid membranes. ${ }^{1,12)}$ In liposome-mediated labeling of the fragments of ACTH with a hydrophobic photolabel, the hydrophobicity was correlated with their biological activities. ${ }^{13)}$ They also reported that the amphiphilic primary structure of ACTH 1-24, based on the segmental distribution of hydrophilic and hydrophobic amino acids in the primary structure, was essential for peptide-membrane interaction. ${ }^{14,15)}$ Based on these reports, our synthetic peptides might also first bind to lipids in the receptors on fat cells and this interaction might initiate the sequence of lipolysis.

Lopez et al. ${ }^{16)}$ reported that calcium ions are required for the optimum fat mobilizing effect at $\mathrm{ACTH}$ on adipose tissue slices in vitro. In this study, we found that calcium ions were necessary for lipolytic action of all the peptides except Arg-Glu-Phe-Phe-Phe, which had a stimulatory effect on lipolysis even when calcium ions were not added to the reaction mixture (Table IV). These results indicated that the mechanism of lipolysis stimulated by Arg-Glu-Phe-Phe-Phe is different from that stimulated by the other peptides. However, the lipolytic action of Arg-Glu-Phe-Phe-Phe like those of Arg-Glu-Gly-Phe-Phe-Phe and ACTH was blocked by a $\beta$-adrenergic blocker but not by an $\alpha$-blocker (Table V).

Hirata and Axelrod ${ }^{18)}$ reported that catecholamine, a neurotransmitter, peptides, and immunoglobulin interacting with cell surface receptors indicated a cascade of biochemical and physical changes in a local domain of the membrane, and that this led to increased mobility of receptors, elevated phospholipid methylation, calcium influx, the generation of c-AMP, histamine release, mitogenesis, and chemotaxis. Our synthetic peptides might be 
considered to cooperatively assist the mobility and to stabilize cell membrane for the action, beside their weak hormonal activity, because the concentration of peptides used in our study is rather high to affect the activity and the peptides are amphiphilic. The different requirements for calcium ion might also result from some synthetic peptides having a glycine residue that assists in the mobility of the cell membrane, while some have no glycine residue. However, there is little evidence to explain the above data, though the results obtained in this experiment may provide keys to expain the mechanism of the lipolytic action of peptides and of the peptides receptor interaction. Therefore, new systems of biochemical experiments have to be introduced. The experiments are now in progress on the mechanism by which the peptides elicited FFA release from fat cells.

\section{REFERENCES}

1) H. Masuno, T. Ohara, A. Ide and H. Okuda, J. Biochem., 95, 1083 (1984)

2) G. Weitzel, K. Eisele and W. Stock, Hoppe-Seyler's Z. Physiol. Chem., 356, 583 (1975).
3) G. I. Tesser, R. Marier, L. Schenkel-Hulinger, P. L. Barthe, B. Kamber and W. Rittel, Acta Endocrinol., 74, 56 (1973).

4) B. Iselin, W. Rittel, P. Sieber and R. Schwyzer, Helv. Chim. Acta, 40, 373 (1957).

5) E. Sandrin and R. A. Boissonnas, Helv. Chim. Acta, 46, 1637 (1963).

6) M. Rodbell, J. Biol. Chem., 239, 375 (1964).

7) N. Yamasaki, A. Ide, H. Masuno and H. Okuda, Agric. Biol. Chem., 46, 1403 (1982).

8) R. Schwyzer, Ann. N. Y. Acad. Sci., 297, 3 (1977).

9) E. T. Kaiser and F. J. Kezdy, Proc. Natl. Acad. Sci. U. S. A., 80, 1137 (1983).

10) H. H. Loh and P. Y. Law, Ann. Rev. Pharmacol. Toxicol., 20, 201 (1980).

11) P. Schoch, D. F. Sargent and R. Schwyzer, Biochem. Soc. Trans., 7, 846 (1979).

12) H. U. Gremlich, D. F. Sargent and R. Schwyzer, Biophys. Struct. Mech., 8, 61 (1981).

13) B. Gysin and R. Schwyzer, FEBS Lett., 158, 12 (1983).

14) B. Gysin and R. Schwyzer, Biochemistry, 23, 1811 (1984).

15) H. U. Gremlich, U. P. Fringeli and R. Schwyzer, Biochemistry, 23, 1808 (1984).

16) E. Lopez, E. White and F. L. Engel, J. Biol. Chem., 234, 2254 (1959).

17) K. Fahlholt, B. Lund and W. Fahlholt, Clin. Chim. Acta, 46, 105 (1973).

18) F. Hirata and J. Axelrod, Science, 209, 1082 (1980). 